\title{
NUCLEAR WEAPONS BEFORE THE INTERNATIONAL COURT OF JUSTICE: A CRITIQUE OF THE MARSHALL ISLANDS V UNITED KINGDOM DECISION
}

\author{
Devesh Awmee*
}

The International Court of Justice recently gave judgment in Obligations Concerning Negotiations Relating to Cessation of the Nuclear Arms Race and to Nuclear Disarmament. The case concerned three parallel claims brought by the Marshall Islands against India, Pakistan and the United Kingdom for their alleged failure to fulfil obligations concerning negotiations relating to the cessation of the nuclear arms race and nuclear disarmament under art VI of the Non-Proliferation Treaty and customary international law. The Court in all three proceedings dismissed the claims at the preliminary objections phase on the sole ground that a legal dispute did not exist between the parties. In determining whether a legal dispute existed, the Court appears to have deviated from the objective determination taken in its previous jurisprudence by introducing, for the first time, a new requirement of "awareness". The Court also failed to address the other preliminary objections brought by the United Kingdom such as the Monetary Gold principle, which appears to have been a more credible avenue for the Court to dismiss the case. The case illustrates the failure by the Court to yet again confront the issue of nuclear weapons.

\section{INTRODUCTION}

On 5 October 2016, the International Court of Justice (ICJ) handed down its judgment in three parallel proceedings regarding nuclear disarmament in its decision in Obligations Concerning Negotiations Relating to Cessation of the Nuclear Arms Race and to Nuclear Disarmament. ${ }^{1}$ The

* Submitted as part of the LLB (Hons) programme at Victoria University of Wellington. I would like to thank my supervisor, Professor Alberto Costi, for his invaluable guidance and support. All errors are, of course, my own.

1 Obligations Concerning Negotiations Relating to Cessation of the Nuclear Arms Race and to Nuclear Disarmament (Marshall Islands v United Kingdom) (Preliminary Objections) [2016] ICJ Rep 833 [Marshall Islands v United Kingdom]; Obligations Concerning Negotiations Relating to Cessation of the Nuclear Arms Race and to Nuclear Disarmament (Marshall Islands v India) (Jurisdiction and Admissibility) [2016] ICJ Rep 
cases brought by the Marshall Islands concerned alleged breaches of the Treaty on the NonProliferation of Nuclear Weapons (NPT) ${ }^{2}$ and customary international law by the United Kingdom, India and Pakistan (as respondents). The Court, in a majority judgment, declined to exercise its jurisdiction to determine the cases on the basis that no legal dispute existed between the parties. ${ }^{3}$

This is the third time the ICJ has confronted an issue regarding nuclear weapons. ${ }^{4}$ There was hope that the ICJ would provide its opinion on the issue, particularly since there was momentum by a majority of the members of the United Nations (UN) to negotiate a treaty prohibiting nuclear weapons. ${ }^{5}$ Instead, the Court declined to exercise its jurisdiction on the sole ground of there being no legal dispute between the parties. ${ }^{6}$ The case is significant for the following three reasons. First, in determining whether a dispute existed between the parties, the Court diverted from the objective approach taken in previous cases. Secondly, this is the third time the Court has had the opportunity to deal with the issue of nuclear weapons. Finally, the case shows that the role of the ICJ in cases involving nuclear weapons is obsolete and that it is a matter which can only be resolved politically.

This article will present and critique the judgment of the ICJ. To this end, Part II will introduce the history and emergence of a nuclear weapons regime at international law. Part III will outline the factual background of the case and the arguments of the parties. Part IV will briefly outline the jurisdiction of the ICJ and the approach taken by the ICJ in determining the existence of a dispute. It will also outline other nuclear weapon issues which have come before the ICJ. Part V will set out the decision of the ICJ. Part VI will critique the Court's reasoning. It will argue that the Court should not have introduced the requirement of "awareness" in determining whether a dispute exists. Moreover, it will argue that the Court ought to have dismissed the case because the legal interests of other nuclear weapon states who were absent in these proceedings formed the subject matter of the decision. ${ }^{7}$

255 [Marshall Islands v India]; and Obligations Concerning Negotiations Relating to Cessation of the Nuclear Arms Race and to Nuclear Disarmament (Marshall Islands $v$ Pakistan) (Jurisdiction and Admissibility) [2016] ICJ Rep 552 [Marshall Islands v Pakistan].

2 Treaty on the Non-Proliferation of Nuclear Weapons 729 UNTS 161 (opened for signature 1 July 1968, entered into force 5 March 1970) [NPT].

3 Subject to context, "Court" refers to the majority.

4 See Nuclear Tests Case (New Zealand v France) [1974] ICJ Rep 457 [New Zealand v France 1974]; Nuclear Tests Case (Australia v France) [1974] ICJ Rep 253 [Australia v France 1974]; Request for an Examination of the Situation in Accordance with Paragraph 63 of the Court's Judgment of 20 December 1974 in the Nuclear Tests (New Zealand v France) Case [1995] ICJ Rep 288 [New Zealand v France 1995]; and Legality of the Threat or Use of Nuclear Weapons (Advisory Opinion) [1996] ICJ Rep 226 [1996 Advisory Opinion].

5 Taking Forward Multilateral Nuclear Disarmament Negotiations GA Res 70/33, A/Res/70/33 (2015).

6 Marshall Islands v United Kingdom, above n 1, at 900 per Judge Bennouna dissenting.

7 Monetary Gold Removed from Rome in 1943 (Italy v France, United Kingdom and United States) (Preliminary Objections) [1954] ICJ Rep 19 [Monetary Gold] at 32. 
Finally, Part VII will address the future of nuclear weapons and focus on the ICJ's capability to deal with such issues. It will also address the reality of achieving nuclear disarmament. Although the case also raises issues of state responsibility, this issue is beyond the scope of this article.

\section{THE EMERGENCE OF A NUCLEAR WEAPONS REGIME}

Many nations have felt the wrath and flow on effects of nuclear weapons ever since two bombs fell over Hiroshima and Nagasaki in 1945. Since then, there have been a further 2,053 nuclear explosions in the manufacturing or testing of nuclear weapons. ${ }^{8}$ As of 2017 , there are around 15,000 nuclear weapons known to exist. ${ }^{9}$ This number is likely to increase because of the escalation of Iran's and North Korea's nuclear and ballistic missile programme. ${ }^{10}$ Countries are also likely to continue upgrading and increasing their nuclear arsenals. ${ }^{11}$

The threat of nuclear weapons has not been ignored. ${ }^{12}$ The Security Council has declared that nuclear weapons are a threat to international peace and security. ${ }^{13}$ A majority of the General Assembly has also shown its concern and disapproval of nuclear weapons. It has expressly proclaimed the use of nuclear weapons as a direct violation of the UN Charter and international law, ${ }^{14}$ with some stating that the only defence against a nuclear catastrophe is to eliminate all nuclear weapons. ${ }^{15}$ The effect of

8 Alessandra Pietrobon "Nuclear Powers' Disarmament Obligation under the Treaty on the Non-Proliferation of Nuclear Weapons and the Comprehensive Nuclear Test Ban Treaty: Interactions between Soft Law and Hard Law" (2014) 27 LJIL 169 at 170.

9 Hans M Kristensen and Robert S Norris "Status of World Nuclear Forces" (8 July 2017) Federation of American Scientists <www.fas.org>.

10 SC Res 2371, S/Res/2371 (2017). See also Peter Kenyon "Did Iran's Ballistic Missile Test Violate a UN Resolution?" (3 February 2017) National Public Radio <www.npr.org>.

11 WJ Hennigan and Ralph Vartabedian "Upgrading US nuclear missiles, as Russia and China modernize, would cost $\$ 85$ billion. Is it time to quit the ICBM race?" Los Angeles Times (online ed, Los Angeles, 30 May 2017).

12 Tom Coppen The Law of Arms Control and the International Non-proliferation Regime (Brill, Leiden, 2016) at 1 .

13 SC Res 1540, S/Res/1540 (2004); SC Res 1977, S/Res/1977 (2011); SC Res 2094, S/Res/2094 (2013); and SC Res 2105, S/Res/2105 (2013).

14 Declaration on the prohibition of the use of nuclear and thermos-nuclear weapons GA Res 1653, XVI (1961); Non-Use of Nuclear Weapons and Prevention of Nuclear War GA Res 33/71B, A/Res/33/71B (1978); NonUse of Nuclear Weapons and Prevention of Nuclear War GA Res 34/83G, A/Res/34/83G (1979); Non-Use of Nuclear Weapons and Prevention of Nuclear War GA Res 35/152D, A/Res/35/152D (1980); Convention on the Prohibition of the Use of Nuclear Weapons GA Res 46/37D, A/Res/46/37D (1991); Convention on the Prohibition of the Use of Nuclear Weapons GA Res 65/80, A/Res/65/80 (2010); Convention on the Prohibition of the Use of Nuclear Weapons GA Res 70/62, A/Res/70/62 (2015); and Universal Declaration on the Achievement of a Nuclear-Weapon-Free World GA Res 70/57, A/Res/70/57 (2015).

15 Follow-up to the advisory opinion of the International Court of Justice on the legality of the threat or use of nuclear weapons GA Res 70/56, A/Res/70/56 (2015); and Follow-up to the advisory opinion of the 
these resolutions indicates the support and development of a legal regime and a customary international law obligation prohibiting nuclear weapons and achieving disarmament. ${ }^{16}$

The drive by a majority of $\mathrm{UN}$ members to create a legal regime governing nuclear weapons is further reflected through several multilateral treaties, ${ }^{17}$ the most significant ones being the Treaty on the Non-Proliferation of Nuclear Weapons (NPT) ${ }^{18}$ and recently the negotiated Treaty on the Prohibition of Nuclear Weapons. ${ }^{19}$

\section{A Treaty on the Non-Proliferation of Nuclear Weapons}

The NPT entered into force in March $1970 .{ }^{20}$ It is the only instrument containing norms on nonproliferation and nuclear disarmament which apply nearly universally due to its expansive membership. ${ }^{21}$ Parties to the NPT are divided into nuclear weapon states (NWS) and non-nuclear weapon states (NNWS). ${ }^{22}$ Article VI codifies the treaty's disarmament objective. It obliges NWS to: ${ }^{23}$

... pursue negotiation in good faith on effective measures relating to cessation of the nuclear arms race at an early date and to nuclear disarmament, and on a treaty on general and complete disarmament under strict and effective international control.

International Court of Justice on the legality of the threat or use of nuclear weapons GA Res 69/43, A/Res/69/43 (2014).

16 Marshall Islands $v$ United Kingdom, above n 1, at [44] per Judge Cançado Trindade dissenting; and 1996 Advisory Opinion, above n 4, at 255. See also Anguel Anastassov "Are Nuclear Weapons Illegal? The Role of Public International Law and the International Court of Justice" (2010) 15 JCSL 65 at 72.

17 See Comprehensive Nuclear Test-Ban Treaty (opened for signature 24 September 1996, not yet in force); International Convention for the Suppression of Acts of Nuclear Terrorism 2445 UNTS 89 (opened for signature 14 September 2005, entered into force 7 July 2007); Treaty Banning Nuclear Tests in the Atmosphere, in Outer Space and Under Water 480 UNTS 43 (opened for signature 5 August 1963, entered into force 10 October 1963); and Treaty on the Prohibition of the Emplacement of Nuclear Weapons and Other Weapons of Mass Destruction on the Seabed and Ocean Floor and in the Subsoil Thereof 955 UNTS 115 (opened for signature 11 February 1971, entered into force 18 May 1972).

18 NPT, above n 2.

19 Treaty on the Prohibition of Nuclear Weapons (opened for signature 20 September 2017, not yet in force).

20 United Nations Office for Disarmament Affairs "Treaty on the Non-Proliferation of Nuclear Weapons (NPT)" <www.un.org>

21 As of May 2018, 191 states are party to the NPT.

22 NPT, above $\mathrm{n} 2$, arts I-II.

23 Article VI. 
The interpretation of art VI has differed between NWS and NNWS as to what measures are needed to comply with it. ${ }^{24}$ NWS interpret it as emphasising the reduction of nuclear arms, while NNWS interpret it as an obligation to achieve a specific result of nuclear disarmament. ${ }^{25}$ According to the ICJ, art VI goes beyond "a mere obligation of conduct". ${ }^{26}$ Instead, the obligation under this article imposes a positive obligation to "achieve a precise result" of nuclear disarmament through negotiations in good faith. ${ }^{27}$ Therefore, just paying lip service to the idea of negotiations does not suffice. $^{28}$ This interpretation was upheld at the 2010 NPT Review Conference. ${ }^{29}$

The original life span of the NPT was 25 years. ${ }^{30}$ However, in 1995, states agreed to extend the duration of the NPT indefinitely. ${ }^{31}$ Since entering into force, the NPT has been successful in curtailing nuclear proliferation. A recent study has shown that NPT ratification has significantly reduced the probability that states will pursue or acquire nuclear weapons. ${ }^{32}$ As of 2018 , four out of the nine NWS are still not party to the NPT. ${ }^{33}$

\section{B Treaty on the Prohibition of Nuclear Weapons}

The Treaty on the Prohibition of Nuclear Weapons was adopted by a majority of UN members in July $2017 .{ }^{34}$ It is the first multilateral legally binding instrument for nuclear disarmament to have been negotiated. ${ }^{35}$ It was adopted by a vote of 122 in favour of the Treaty. ${ }^{36}$ The Netherlands voted against

24 Daniel H Joyner "The Legal Meaning and Implications of Article VI of the Non-Proliferation Treaty" in Gro Nystuen, Stuart Casey-Maslen and Annie Golden Bersagel Nuclear Weapons under International Law (Cambridge University Press, Cambridge, 2014) 397 at 397.

25 At 404.

261996 Advisory Opinion, above n 4, at [99].

27 At [99].

28 Joyner, above n 24 , at 417.

292010 Review Conference of the Parties to the Treaty on the Non-Proliferation of Nuclear Weapons NPT/CONF.2010/50 (Vol I) (2010) at [79].

30 NPT, above n 2, art X(2).

311995 Review and Extension of the Parties to the Treaty on the Non-Proliferation of Nuclear Weapons NPT/CONF.1995/32 (Part I) (1995).

32 See Matthew Fuhrmann and Yonatan Lupu "Do Arms Control Treaties Work? Assessing the Effectiveness of the Nuclear Nonproliferation Treaty" (2016) 60 ISQ 530 at 533.

33 These states include India, Israel, Pakistan and North Korea.

34 UN News "UN Member States set to adopt 'historic' treaty prohibiting nuclear weapons" (6 July 2017) <https://news.un.org>.

35 UN News, above n 34.

36 UN News "UN conference adopts treaty banning nuclear weapons" (7 July 2017) <https://news.un.org>. 
it and Singapore abstained. ${ }^{37}$ The Treaty opened for signature in September 2017. ${ }^{38}$ It must be ratified by 50 states to enter into force. ${ }^{39}$ As of May 2018, 58 states have signed the Treaty and 10 have ratified it. ${ }^{40}$ It is important to note that none of these states are NWS.

The Treaty emphasises an attempt by a majority of the international community to create a legal regime against nuclear weapons. Article 1 outlines the prohibitions imposed on each state once they become party to the Treaty. Each state party undertakes to never under any circumstances develop, manufacture, test, transfer, receive, and use nuclear weapons. ${ }^{41}$ The Treaty also requires state parties who possess nuclear weapons to destroy them. ${ }^{42}$ These obligations are to be implemented and enforced by each state party taking legal and administrative action to sanction nuclear weapon activities within their territories. ${ }^{43}$ State parties are also required to cooperate and meet regularly to facilitate the implementation of the Treaty and ensure that their obligations are (being) fulfilled. ${ }^{44}$

Despite this attempt to create a comprehensive legal regime, it must be noted that NWS and many of their allies did not take part in the negotiations. ${ }^{45}$ Notable of these countries were the United States, United Kingdom, Russia, China, France, India, Pakistan, Israel and North Korea. ${ }^{46}$ Unfortunately, this continued tension between NWS and NNWS hampers an attempt to create a successful legal regime and prevents the emergence of a customary prohibition. ${ }^{47}$ However, it has been acknowledged that: ${ }^{48}$

While the treaty itself will not immediately eliminate any nuclear weapons, the treaty can, over time, further delegitimize nuclear weapons and strengthen the legal and political norm against their use.

37 UN News, above n 36.

38 Treaty on the Prohibition of Nuclear Weapons, above n 19, art 13.

39 Article 15.

40 United Nations Treaty Collection "Treaty on the Prohibition of Nuclear Weapons" (27 May 2018) <www.treaties.un.org>.

41 Treaty on the Prohibition of Nuclear Weapons, above n 19, art 1.

42 Article 4(2).

43 Article 5.

44 Articles 7(1) and 8(1).

45 Nuclear Threat Initiative "Treaty on the Prohibition of Nuclear Weapons" (13 July 2017) <www.nti.org>.

46 Rick Gladstone "The UN Adopts a Treaty to Ban Nuclear Weapons. Now Comes the Hard Part" The New York Times (New York, 8 July 2017) at A7.

471996 Advisory Opinion, above n 4, at [73].

48 Daryl G Kimball "New Nuclear Weapons Prohibition Treaty Marks a Turning Point" (7 July 2017) Arms Control Association <www.armscontrol.org>. 


\section{THE EMERGENCE OF THE DISPUTE}

\section{A History}

It is important to acknowledge the Marshall Islands' experience with nuclear weapons to illustrate the driving forces behind their proceedings. After World War II, the United States was responsible for administering and looking after the welfare of the Marshall Islands. Yet, between 1946 and 1958, the United States tested 67 nuclear weapons in the Marshall Islands. ${ }^{49}$ The effects of these detonations have left parts of the Marshall Islands uninhabitable to this day. ${ }^{50}$ The Marshallese people also continue to suffer one of the highest rates of thyroid cancer and birth defects related to radiation in the world. ${ }^{51}$ However, despite these tragedies, there appears to be no evidence available to show that the Marshall Islands ever raised any of their concerns about nuclear weapons directly with any of the NWS prior to filing proceedings before the ICJ.

\section{B Proceedings before the ICJ}

On 24 April 2014, the Marshall Islands filed proceedings in the Registry of the Court against the United Kingdom, China, North Korea, France, India, Israel, Pakistan, Russia and the United States. ${ }^{52}$ The Marshall Islands alleged that these states breached their obligations to fulfil negotiations relating to the cessation of the nuclear arms race and nuclear disarmament under art VI of the NPT and international customary law. ${ }^{53}$ However, only the proceedings against the United Kingdom, Pakistan and India proceeded as they were the only three states that made optional declarations recognising the compulsory jurisdiction of the Court pursuant to art 36(2) of the Statute of the International Court of Justice 1945 (the Statute) ${ }^{54}$ Proceedings against the other states did not proceed on the ground that those states, after being invited to do so, did not consent to the jurisdiction of the Court pursuant to art 38(5) of the International Court of Justice Rules of Court 1978. ${ }^{55}$

49 Kim Skoog "US Nuclear Testing on the Marshall Islands: 1946 to 1958" (2003) 3 Teaching Ethics 67 at 67.

50 "Bikini Atoll nuclear test: 60 years later and islands still unliveable" The Guardian (online ed, United Kingdom, 2 March 2014).

51 United Nations Human Rights Council Report of the Special Rapporteur on the Implications for Human Rights of the Environmentally Sound Management and Disposal of Hazardous Substances and Wastes on his Mission to the Marshall Islands and the United States of America 21/48/Add.1, A/HRC/21/48/Add.1 (2012) at $[30]-[31]$.

52 International Court of Justice "The Republic of the Marshall Islands Files Applications against nine States for their alleged failure to fulfil their obligations with respect to the cessation of the nuclear arms race at an early date and to nuclear disarmament" (press release, 25 April 2014).

53 Marshall Islands v United Kingdom, above n 1, at [22] per the majority.

54 At [22] per the majority.

55 At [22] per the majority. 
The Marshall Islands claimed the three respondent states failed to meet their obligations to negotiate the cessation of the nuclear arms race and nuclear disarmament in good faith. ${ }^{56}$ This obligation was alleged to derive from art VI of the NPT and customary international law. ${ }^{57}$ It was also alleged that efforts by the three respondent states to modernise and maintain their nuclear arsenal had breached art VI and customary international law. ${ }^{58}$ The Marshall Islands and the United Kingdom are parties to the NPT while Pakistan and India are not. Due to the constraints of this article, only the proceedings against the United Kingdom will be dealt with.

The Marshall Islands was seeking that the Court declare that the United Kingdom was in breach of its obligations and that the Court order the United Kingdom to take all steps necessary to comply with its obligations under art VI of the NPT and customary international law. ${ }^{59}$

\section{$C$ Arguments of the Parties}

Before proceeding to the merits, the ICJ must first give judgment on any preliminary objections raised by the respondent challenging the Court's jurisdiction. ${ }^{60}$ The case before the Court was at the preliminary objections phase as the United Kingdom had filed preliminary objections challenging the Court's jurisdiction and the admissibility of the claims put forward by the Marshall Islands.

\section{United Kingdom}

The United Kingdom advanced, inter alia, the argument that the Court had no jurisdiction to proceed with the case on the grounds that the Marshall Islands had failed to show the existence of a dispute between the parties with respect to an alleged failure to pursue negotiations in good faith towards the cessation of nuclear arms and nuclear disarmament. ${ }^{61}$ The United Kingdom argued that an applicant must give prior notice of its claims to the respondent to establish a dispute. ${ }^{62}$ It relied on art 43 of the International Law Commission's articles on the Responsibility of States for

56 Marshall Islands $v$ United Kingdom, above n 1, at [11] per the majority; Marshall Islands v India, above n 1, at [11] per the majority; and Marshall Islands v Pakistan, above n 1, at [11] per the majority.

57 Marshall Islands $v$ United Kingdom, above n 1, at [11] per the majority; Marshall Islands v India, above n 1, at [11] per the majority; and Marshall Islands v Pakistan, above n 1, at [11] per the majority.

58 Marshall Islands $v$ United Kingdom, above n 1, at [11] per the majority; Marshall Islands v India, above n 1, at [11] per the majority; and Marshall Islands v Pakistan, above n 1, at [11] per the majority.

59 Marshall Islands $v$ United Kingdom, above n 1, at [11] per the majority.

60 International Court of Justice Rules of Court 1978, art 79(9).

61 Marshall Islands v United Kingdom, above n 1, at [23] per the majority.

62 At [27] per the majority. 
Internationally Wrongful Acts, which states that "[a]n injured State which invokes the responsibility of another State shall give notice of its claim to that State. "63

The United Kingdom also put forward four other preliminary objections ${ }^{64}$ However, the Court regrettably did not address these. ${ }^{65}$ Of interest to this article, one of these arguments, acknowledged by a few of the judges, was that the Court should have refused to exercise its jurisdiction because the legal interests of other NWS, who were absent in these proceedings, would have formed the subject matter of the decision. ${ }^{66}$ This is known as the Monetary Gold principle. ${ }^{67}$ It will be addressed in Part VI.

\section{Marshall Islands}

As the case was at the preliminary objections phase, the Court only focused on the existence of a dispute and not on the substance of the case. ${ }^{68}$ Therefore, the Marshall Islands did not discuss its nuclear weapon concerns. The Marshall Islands contended that a dispute did exist, arguing that statements made in multilateral settings prior to the filing of the application had established the existence of a dispute with the United Kingdom. ${ }^{69}$ For instance, during a General Assembly meeting in September 2013, the Marshall Islands had urged all NWS "to intensify efforts to address their responsibilities in moving towards an effective and secure disarmament". ${ }^{70}$ A further statement by the Marshall Islands at an international conference in Nayarit in February 2014 asserted that "States possessing nuclear arsenals are failing to fulfil their legal obligations" under customary international law and art VI of the NPT. ${ }^{71}$ The United Kingdom was not present at this conference. ${ }^{72}$

The Marshall Islands also argued that the voting records in multilateral fora regarding nuclear weapons demonstrated the existence of a legal dispute. ${ }^{73}$ It particularly relied on General Assembly

63 Draft Articles on Responsibility of States for Internationally Wrongful Acts [2001] vol 2 pt 2 YILC 26 at 29.

64 Marshall Islands v United Kingdom, above n 1, at [23] per the majority.

65 At [58] per the majority.

66 At [39] per Judge Tomka (separate opinion), [11] per Judge Xue, [18]-[19] per Judge Bhandari and [32]-[33] per Judge Crawford dissenting.

67 Monetary Gold, above n 7, at 32.

68 Dan Ciobanu Preliminary Objections: Related to the Jurisdiction of the United Nations Political Organs (Springer, Netherlands, 1975) at 62.

69 Marshall Islands v United Kingdom, above n 1, at [48] per the majority.

70 At [49] per the majority.

71 At [50] per the majority.

72 At [28] per the majority.

73 At [35] per the majority. 
Resolution 68/32, where the General Assembly called for the "urgent compliance with the legal obligations and the fulfilment of the commitments undertaken on nuclear disarmament". ${ }^{74}$ The Marshall Islands voted in favour of the resolution while the United Kingdom voted against it. ${ }^{75}$

Alternatively, the Marshall Islands argued that the filing of the application itself and the opposing views expressed by the United Kingdom during the ICJ proceedings were enough to demonstrate the existence of a dispute. ${ }^{76}$

\section{THE INTERNATIONAL COURT OF JUSTICE}

The ICJ is a legal organ of the UN. ${ }^{77}$ It is the successor to the Permanent Court of International Justice (PCIJ). Its scope is to ascertain and decide legal disputes between states in accordance with international law. ${ }^{78}$

\section{A Jurisdiction of the ICJ}

All UN members have access to the ICJ. ${ }^{79}$ However, for the ICJ to exercise its competence, states must consent to its jurisdiction. ${ }^{80}$ The justification for this derives from the concept that states are sovereign. ${ }^{81}$ Sovereignty allows a state to choose whether to allow a superior authority to take a decision of a state's affairs out of its hands. ${ }^{82}$

Consent can be in the form of an agreement where the states have agreed to have their dispute settled by the ICJ. ${ }^{83}$ It can also derive from a jurisdiction clause in a treaty which both states are party to. ${ }^{84} \mathrm{~A}$ state can also be invited to consent to the jurisdiction of the Court under art 38(5) of the International Court of Justice Rules of Court. ${ }^{85}$ Consent can also be obtained through a doctrine

74 Follow-up to the 2013 high-level meeting of the General Assembly on nuclear disarmament GA Res 68/32, $\mathrm{A} / \operatorname{Res} / 68 / 32$ (2013) at [2].

75 Marshall Islands v United Kingdom, above n 1, at [55] per the majority.

76 At [46] per the majority.

77 Hugh Thirlway The International Court of Justice (Oxford University Press, New York, 2016) at 3.

78 Statute of the International Court of Justice 1945, art 38(1).

79 Thirlway, above $\mathrm{n} 77$, at 3 .

80 JG Merrills International Dispute Settlement (5th ed, Cambridge University Press, New York, 2011) at 116.

81 Robert Kolb The International Court of Justice (Hart Publishing, Portland (OR), 2013) at 370.

82 At 370

83 Statute of the International Court of Justice, art 36(1). See also Shabtai Rosenne The World Court: What It Is and How It Works (4th ed, Martinus Nijhoff Publishers, Dordrecht, 1989) at 84.

84 Merrills, above n 80, at 117.

85 International Court of Justice Rules of Court, art 38(5). 
known as forum prorogatum. ${ }^{86}$ This doctrine allows consent to be obtained without any formal statement of acceptance of the Court's jurisdiction. ${ }^{87}$ Thus, if the respondent state's conduct amounts to "an unequivocal indication" of its acceptance of the Court's jurisdiction, then this can amount to consent. ${ }^{88}$

A state can also give its consent through an "optional clause" declaration, which recognises the Court has compulsory jurisdiction in all legal disputes with other states that have accepted the Court's jurisdiction. ${ }^{89}$ These declarations can be accompanied by reservations that allow a state to set conditions and limitations on the ICJ's compulsory jurisdiction. ${ }^{90}$ If consent is given through an "optional clause" declaration, then this does not stop a respondent state from raising preliminary objections to prevent the case from proceeding to the merits. ${ }^{91}$ The Marshall Islands and the United Kingdom have consented to the ICJ's jurisdiction through an "optional clause" declaration. ${ }^{92}$

\section{$B$ The ICJ and the Existence of Disputes between States}

The jurisdiction of the ICJ in inter-state disputes is of an adversarial nature. It extends only to "legal disputes" between states, making the existence of one a key requirement. ${ }^{93}$ The test for a dispute is minimal and does not entertain a demanding threshold. ${ }^{94}$ The Statute states that the Court will exercise its jurisdiction in all legal disputes concerning the interpretation of a treaty, a question of international law, the existence of any fact that would constitute a breach of an international obligation, or the nature or extent of the reparation to be made for the breach of an international obligation. ${ }^{95}$

86 Merrills, above n 80, at 118.

87 Armed Activities on the Territory of the Congo (Democratic Republic of the Conga v Rwanda) (Jurisdiction and Admissibility) [2006] ICJ Rep 6 at [21] per the majority.

88 At [21] per the majority.

89 Statute of the International Court of Justice, art 36(2)

90 Article 36(3). See also Vanda Lamm Compulsory Jurisdiction in International Law (Edward Elgar Publishing, Cheltenham, 2014) at 61-62.

91 International Court of Justice Rules of Court, art 79.

92 See "Declarations recognizing the jurisdiction of the Court as compulsory: Marshall Islands" (24 April 2013) International Court of Justice <www.icj-cij.org>; and "Declarations recognizing the jurisdiction of the Court as compulsory: United Kingdom of Great Britain and Northern Ireland" (22 February 2017) International Court of Justice <www.icj-cij.org>.

93 Andreas Zimmermann "Article 35" in Andreas Zimmermann and others (eds) The Statute of the International Court of Justice: A Commentary (Oxford University Press, New York, 2006) 565 at 587.

94 Marshall Islands v United Kingdom, above n 1, at [2] per Judge Crawford dissenting.

95 Statute of the International Court of Justice, art 36(2). 
The meaning of "legal dispute" is not defined in the Statute. In the Mavrommatis decision, the PCIJ defined dispute as "a disagreement on a point of law or fact, a conflict of legal views or interests between two persons". 96 This definition has been upheld without significant modification by the ICJ, except that it has now been clarified that a dispute can exist among more than two states. ${ }^{97}$ The determination of a dispute has been particularised in later ICJ cases. The ICJ has stated in the South West Africa cases that it must be shown that "the claim of one party is positively opposed by the other".$^{98}$ It has been emphasised that the existence of a dispute is a matter for objective determination and it is not enough for one party to assert that there is a dispute. ${ }^{99}$ A conflict based on political grounds would not suffice. ${ }^{100}$ However, this will not deprive the Court of its competence to hear a case on a legal dispute which contains political elements. ${ }^{101}$ Furthermore, the fact that a state appears to challenge the jurisdiction of the Court does not mean there is a dispute. ${ }^{102}$

\section{ICJ, Disputes and Nuclear Weapons}

The Court has had the opportunity to address disputes regarding nuclear weapons in the Nuclear Test Cases of 1974 and 1995. ${ }^{103}$ The Court has also had the opportunity to exercise its advisory function in respect of the legality of nuclear weapons. ${ }^{104}$ However, the reasoning and conclusions in these decisions show that the Court has been reluctant to engage with nuclear weapon related questions. ${ }^{105}$ This section will outline the cases and advisory opinion.

96 The Mavrommatis Palestine Concessions (Greece v United Kingdom) (Jurisdiction) (1924) PCIJ (series A) No 2 at 11 .

97 Certain Property (Liechtenstein v Germany) (Preliminary Objections) [2005] ICJ Rep 6 at 18.

98 South West Africa Cases (Ethiopia v South Africa; Liberia v South Africa) (Preliminary Objections) [1962] ICJ Rep 319 at 328.

99 Interpretation of Peace Treaties with Bulgaria, Hungary and Romania (Advisory Opinion) [1950] ICJ Rep 65 at 74 .

100 Christian Tomuschat "Article 36" in Andreas Zimmermann and others (eds) The Statute of the International Court of Justice: A Commentary (Oxford University Press, New York, 2006) 589 at 597.

101 Military and Paramilitary Activities in and against Nicaragua (Nicaragua v United States) (Merits) [1986] ICJ Rep 14 [Nicaragua v United States] at [33].

$102 \mathrm{Kolb}$, above n 81, at 316.

103 See New Zealand v France 1974, above n 4; Australia v France 1974, above n 4; and New Zealand v France 1995, above n 4.

104 See 1996 Advisory Opinion, above n 4.

105 Surabhi Ranganathan "Nuclear Weapons and the Court" (2017) 111 AJIL 88 at 88. 


\section{Nuclear tests cases}

This case was brought to the ICJ by New Zealand and Australia. It concerned atmospheric nuclear tests being conducted by France in the South Pacific. New Zealand contended, inter alia, that these tests violated the rights of New Zealand and other states to not have radioactive material enter its territory, air space and territorial waters. ${ }^{106}$ Australia contended that it was seeking to protect the life and well-being of Australian citizens and other states against nuclear tests. ${ }^{107}$ It must be noted that the Court was not asked to discuss the illegality of nuclear weapons or nuclear disarmament. Instead, New Zealand and Australia sought for the ICJ to declare that nuclear tests were contrary to their rights under international law. ${ }^{108}$

The Court held that a dispute no longer existed between New Zealand, Australia and France. ${ }^{109}$ This is because soon after the proceedings started, France voluntarily announced that it no longer planned to continue atmospheric testing in the South Pacific. ${ }^{110}$ Therefore, the Court did not proceed to give a decision on the merits; the claims of New Zealand and Australia no longer had "any object". ${ }^{111}$ However, the judgment reserved the right for the Court to reopen the case. ${ }^{112}$

New Zealand filed an application to reopen the case in 1995. However, France, this time, was conducting underground nuclear tests as opposed to atmospheric tests. ${ }^{113}$ The ICJ dismissed the application to reopen the case. ${ }^{114}$ The Court held that the complaint was directed against underground nuclear tests and did not fit into the caveat of the 1974 judgment, which concerned atmospheric nuclear tests only. ${ }^{115}$

The Court was not persuasive in deciding to not reopen the case. ${ }^{116}$ The relevant passages of the 1974 judgment were written in general terms and did not mention that New Zealand was restricted to

106 New Zealand v France 1974, above n 4, at 464.

107 Australia v France 1974, above n 4, at 261.

108 New Zealand v France 1974, above n 4, at 460; and Australia v France 1974, above n 4, at 256.

109 New Zealand v France 1974, above n 4, at 476; and Australia v France 1974, above n 4, at 271.

110 New Zealand v France 1974, above n 4, at 476; and Australia v France 1974, above n 4, at 271.

111 New Zealand v France 1974, above n 4, at 476; and Australia v France 1974, above n 4, at 271.

112 New Zealand v France 1974, above n 4, at 477; and Australia v France 1974, above n 4, at 272.

113 Craig R Whitney "France Planning Nuclear Tests Despite Opposition, Chirac Says" The New York Times (New York, 14 June 1995) at A3.

114 New Zealand v France 1995, above n 4, at 307.

115 At 306 .

116 Stephen M Tokarz "A Golden Opportunity Dismissed: The New Zealand v France Nuclear Tests Case" (1998) 26 Denv J Intl L \& Poly 745 at 757. 
filing an application to reopen the case for atmospheric tests only. ${ }^{117}$ Also, the application by New Zealand in the 1974 case did not specify atmospheric nuclear tests, but referred to nuclear tests generally. ${ }^{118}$ Thus, the Court appears to adopt a narrow approach when determining whether to decide issues of global importance. ${ }^{119}$

\section{Advisory Opinion on the Legality of Nuclear Weapons}

The 1996 Advisory Opinion is important as it demonstrated the lack of courage by the ICJ to satisfactorily address the issue of nuclear weapons. ${ }^{120}$ Initially there were two requests for an advisory opinion made by the World Health Organisation (WHO) and the General Assembly under art 65 of the Statute. The WHO requested the Court to advise on the question of the legality of the use of nuclear weapons during armed conflict "in view of their health and environmental effects". ${ }^{121}$ The Court found it was unable to give an advisory opinion because the request did not relate to a question arising "within the scope of [the] activities" of the WHO. ${ }^{122}$

The General Assembly requested the ICJ to determine whether the threat or use of nuclear weapons in any circumstance was permitted under international law. ${ }^{123}$ The Court accepted the request to deliver an advisory opinion. ${ }^{124}$ At the time, the Court accepted there was no treaty or international instrument explicitly prohibiting nuclear weapons. ${ }^{125}$ However, the Court acknowledged the catastrophic characteristics of nuclear weapons and the threat they pose to future generations. ${ }^{126}$ It was also found that nuclear weapons did not discriminate between civilian and military targets and caused unnecessary suffering, thus violating, in theory, "cardinal principles" of the Law of Armed

117 At 756

118 New Zealand v France 1974, above n 4, at 466.

119 See East Timor (Portugal v Australia) (Judgment) [1995] ICJ Rep 90. The Court refused to hear the case between Portugal and Australia because the rights of Indonesia were also affected and Indonesia was not before the Court.

120 Marshall Islands v United Kingdom, above n 1, at [171] per Judge Cançado Trindade dissenting.

121 Legality of the Use by a State of Nuclear Weapons in Armed Conflict (Advisory Opinion) [1996] ICJ Rep 66 at [21].

122 At [31].

123 Request for an advisory opinion from the International Court of Justice on the legality of the threat or use of nuclear weapons GA Res 49/75K, A/Res/49/75K (1994).

1241996 Advisory Opinion, above n 4, at [19].

125 At [33].

126 At [35]. 
Conflict. ${ }^{127}$ Nevertheless, by a frail majority vote requiring the casting vote of the President, ${ }^{128}$ the Court controversially and ambiguously held two propositions: ${ }^{129}$

(1) "the threat or use of nuclear weapons would generally be contrary to the rules of international law applicable in armed conflict, and in particular the principles and rules of humanitarian law"; and

(2) "the Court cannot conclude definitely whether the threat or use of nuclear weapons would be lawful or unlawful in an extreme circumstance of self-defence, in which the very survival of a State would be at stake."

In perhaps the only meaningful pronouncement in the advisory opinion, the Court was unanimous in acknowledging the importance and the binding legal obligation to pursue negotiations relating to nuclear disarmament under art VI of the NPT. ${ }^{130}$

\section{$V$ DECISION OF THE COURT IN MARSHALL ISLANDS V UNITED KINGDOM}

The Court ultimately held, in a rather short judgment, and by the narrowest of majorities requiring the casting vote of the President, ${ }^{131}$ that it had no jurisdiction under art 36(2) of the Statute to proceed with the case as there was no dispute. ${ }^{132}$ Vice-President Yusuf and Judges Tomka, Bennouna, Cançado Trindade, Sebutinde, Robinson, Crawford, and ad hoc Bedjaoui dissented on this point. The reasoning of the Court will now be set out.

\section{A Jurisdiction}

The Court began its reasoning by stating that under art 36(2), the ICJ has jurisdiction over "legal disputes"133 between states who have made "optional clause" declarations accepting the compulsory

127 At [78]. See Gary D Solis The Law of Armed Conflict (Cambridge University Press, New York, 2010) at ch 7 for an overview of the core principles of the Law of Armed Conflict.

128 Marshall Islands v United Kingdom, above n 1, at [165] per Judge Cançado Trindade dissenting; and Dale Stephens "Human Rights and Armed Conflict - The Advisory Opinion of the International Court of Justice in the Nuclear Weapons Case" (2001) 4 YHRDJ 1 at 14.

1291996 Advisory Opinion, above n 4, at [105] (emphasis added).

130 At [103].

131 See Statute of the International Court of Justice, art 55(2).

132 Marshall Islands v United Kingdom, above n 1, at [59] per the majority.

133 At [36] per the majority. 
jurisdiction of the Court. ${ }^{134}$ Thus, the existence of a dispute between states is a condition of the Court's jurisdiction. ${ }^{135}$

\section{B Dismissal of the United Kingdom's Argument Regarding Prior Notice}

At the outset, the Court rejected the argument that the Marshall Islands must give prior "notice of its claim" in compliance with art 43 of the International Law Commission's articles on the Responsibility of the States for Internationally Wrongful Acts to show the existence of a dispute. ${ }^{136}$ The Court emphasised that prior notice was not required to show the existence of a dispute. ${ }^{137}$ The Court also held that art 43 was irrelevant because it was not concerned with questions regarding the ICJ's jurisdiction or the conditions for the admissibility of cases brought before the Court. ${ }^{138}$

\section{$C$ The Requirements for the Existence of a Dispute}

The Court rehearsed the requirements to establish the existence of a dispute, emphasising that the determination of one is a matter of substance, not form. ${ }^{139}$ The Court also accepted the definitions of "dispute" in the Mavrommatis and South West Africa cases. ${ }^{140}$ Furthermore, the Court stated that two parties must "hold clearly opposite views concerning the question of the performance or nonperformance of certain international obligations". ${ }^{141}$ The existence of a dispute can be ascertained from statements, including statements made in multilateral settings, by the parties, or documents exchanged between them prior to the filing of an application, or by the failure of a state to respond to claims in circumstances where a response is expected. ${ }^{142}$ Conduct subsequent to the application being filed may be relevant to confirm or deny the existence of a dispute. ${ }^{143}$ It is also emphasised that prior notification, or a formal diplomatic protest by the applicant are not necessary prerequisites for the

134 At [36] per the majority.

135 At [36] per the majority.

136 At [45] per the majority.

137 At [45] per the majority.

138 At [45] per the majority. See also Draft articles on responsibility of States for internationally wrongful acts, above $n$ 63, at 29 .

139 Marshall Islands v United Kingdom, above n 1, at [38] per the majority.

140 At [37] per the majority.

141 At [37] per the majority.

142 At [39]-[40] per the majority.

143 At [43] per the majority. 
existence of a dispute. ${ }^{144}$ Ultimately, the existence of a dispute "is a matter for objective determination by the Court which must turn on an examination of the facts". 145

In addition to the established jurisprudence on the requirements for establishing a dispute, the Court seems to have added for the first time a new requirement of "awareness"146 by relying on two recent cases. ${ }^{147}$ This requirement states that for a dispute to exist, it must be "demonstrated, on the basis of evidence, that the respondent was aware, or could not have been unaware, that its views were 'positively opposed' by the applicant". ${ }^{148}$ This new requirement is problematic and will be analysed in Part VI because it is at the core of the majority's decision.

\section{$D$ Reasons for Finding that No Dispute Existed}

The Court ultimately rejected the arguments put forward by the Marshall Islands. First, the Court stated that the statements invoked by the Marshall Islands were not sufficient to demonstrate the existence of a dispute. ${ }^{149}$ The statement made in September 2013 was found to be "formulated in hortatory terms" and could not be understood to be an allegation that the United Kingdom was in breach of its obligations. ${ }^{150}$ It also did not specifically identify the United Kingdom. Therefore, the statement lacked the detail and clarity needed to make the United Kingdom aware that its views were opposed by the Marshall Islands.

As regards the February 2014 statement, the Court stated that it went further than the September 2013 statement by criticising the conduct of all NWS. ${ }^{151}$ However, by not naming the United Kingdom directly or specifying the conduct which gave rise to the breach, and the fact it was made at a conference on the humanitarian impact of nuclear weapons, not nuclear disarmament, the statement

144 At [38] per the majority.

145 At [39] per the majority.

146 At [41] per the majority.

147 Alleged Violations of Sovereign Rights and Maritime Spaces in the Caribbean Sea (Nicaragua v Colombia) (Preliminary Objections) [2016] ICJ Rep 3 [Alleged Violations]; and Application of the International Convention on the Elimination of All Forms of Racial Discrimination (Georgia v Russia) (Preliminary Objections) [2011] ICJ Rep 70 [Georgia v Russia].

148 Marshall Islands v United Kingdom, above n 1, at [41] per the majority.

149 At [51] per the majority.

150 At [49] per the majority.

151 At [50] per the majority. 
"did not call for a specific reaction by the United Kingdom". ${ }^{152}$ Therefore, no "opposition of views" could be inferred. ${ }^{153}$

Secondly, the Court noted that care must be taken in drawing inferences from voting patterns within political organs, such as the General Assembly, and that voting patterns in itself cannot demonstrate the existence of a dispute. ${ }^{154}$ This is because a state's vote on any given resolution cannot be "indicative of its position on every proposition within that resolution". 155

Thirdly, the Court rejected the Marshall Islands' argument that the filing of the application itself could demonstrate the existence of a dispute. ${ }^{156}$ The filing of the application could be used as evidence to confirm the continued existence of a dispute or clarify the scope or subject matter of the dispute, but it could not be used to "create a dispute de novo, one that does not already exist". ${ }^{157}$

In considering the arguments put forward by the Marshall Islands, the Court, applying the awareness requirement, held that the lack of specificity in its prior statements on the cessation of nuclear arms and nuclear disarmament meant that the United Kingdom could not be found to have been aware that its views were positively opposed by the Marshall Islands. ${ }^{158}$ This meant the Court had no basis to find that a dispute existed. Therefore, the Court had no power to exercise its jurisdiction under art 36(2) of the Statute to determine the merits of the case. ${ }^{159}$ Consequently, the parties never had the opportunity to address the substantive issues.

\section{E Dissents}

All eight judges in their dissenting opinions would have found that a dispute existed between the Marshall Islands and the United Kingdom on the date the application was filed. ${ }^{160}$ They found that the statements made by the Marshall Islands at the 2013 and 2014 conferences were enough to objectively demonstrate that the parties held opposing views as to their obligations under art VI of the

152 At [50] per the majority.

153 At [50] per the majority.

154 At [56] per the majority.

155 At [56] per the majority.

156 At [54] per the majority.

157 At [54] per the majority.

158 At [57] per the majority.

159 At [58] per the majority.

160 At [60] per Vice-President Yusuf dissenting, [30] per Judge Tomka (separate opinion), [19] per Judge Cançado Trindade dissenting, [34] per Judge Sebutinde (separate opinion), [67] per Judge Robinson dissenting, [31] per Judge Crawford dissenting and 901 per Judge Bennouna dissenting. 
NPT. ${ }^{161}$ Many of the dissenters also expressed their disapproval of the new awareness requirement. ${ }^{162}$ These views will be addressed in detail in Part VI.

\section{A CRITIQUE OF THE REASONING}

This part advances two primary arguments. The first concerns the Court's introduction of a criteria of awareness in determining the existence of a dispute. It will be argued that the Court appears to deviate from past practice by introducing this requirement. The second relates to the Court's refusal to give judgment on the other preliminary objections. Thus, it will be argued that the application of the Monetary Gold principle put forward by the United Kingdom might have been a more credible avenue for the Court to dismiss the case.

\section{A Requirement of Awareness in Finding a Dispute}

The awareness requirement appears to shift the determination of a dispute from a flexible, pragmatic inquiry into a restrictive and formalistic one. Four arguments will be put forward to illustrate that the Court should not have added a requirement of awareness. First, this requirement departs from the Court's objective analysis based on an examination of the facts. Secondly, the two recent cases relied upon do not appear to propose an awareness requirement. Thirdly, the requirement may have startling effects on future cases brought before the ICJ. Finally, this requirement will impact the sound administration of justice and judicial economy.

\section{A departure from an objective analysis}

The existence of a dispute is a necessary requirement for the ICJ to exercise its jurisdiction and the Court has indicated it should be objectively ascertained. ${ }^{163}$ However, the awareness requirement introduced by the Court appears to be a departure from this objective approach. ${ }^{164}$ By requiring the respondent to be aware that its views are opposed by the applicant, the Court has begun to dive into the mind of the respondent state. ${ }^{165}$ This departure is pointed out by Vice-President Yusuf who states: 166

161 At [60] per Vice-President Yusuf dissenting, [30] per Judge Tomka (separate opinion), [16]-[17] per Judge Cançado Trindade dissenting, [25] per Judge Sebutinde (separate opinion), [27] and [29] per Judge Crawford dissenting and [67] per Judge Robinson dissenting.

162 At [3] per Vice-President Yusuf dissenting, [29] per Judge Cançado Trindade dissenting, [30] per Judge Sebutinde (separate opinion), [40] per Judge Robinson dissenting, [6] per Judge Crawford dissenting and 905 per Judge Bennouna dissenting.

163 Interpretation of Peace Treaties with Bulgaria, Hungary and Romania, above n 99, at 74.

164 Meenakshi Ramkumar and Aishwarya Singh "The Nuclear Disarmament Cases: Is Formalistic Rigour in Establishing Jurisdiction Impeding Access to Justice?" (2017) 33 UJIEL 128 at 131.

165 Marshall Islands $v$ United Kingdom, above n 1, at [24] per Judge Robinson dissenting.

166 At [23] per Vice-President Yusuf dissenting. 
The function of the Court is to determine the existence of a conflict of legal views on the basis of evidence placed before it and not to delve into the consciousness, perception and other mental processes of States (provided they do possess such cerebral qualities) in order to find out about their state of awareness.

Vice-President Yusuf's statement emphasises that the ICJ's role is to examine the evidence before the Court in ascertaining whether a dispute exists. However, this requirement impacts on the Court's function to do so. This is due to the existence of a dispute now resting on an inquiry into the knowledge of the respondent, rather than on an objective determination of the facts before the Court. ${ }^{167}$

The introduction of the awareness element is quite ironic considering that in the declaration of President Abraham, who accepted that awareness was a hard requirement, it was stated that the Court must be highly consistent in its jurisprudence in both the interests of legal security and to avoid any suspicion of arbitrariness. ${ }^{168}$ The Court appears to have done the complete opposite. ${ }^{169}$ Instead, it appears to have introduced an element of subjective awareness arbitrarily, which appears to clash with the stated objective determination of whether a dispute exists because the focus shifts to the knowledge of the respondent. ${ }^{170}$

The Court also emphasised multiple times in its judgment that the respondent having prior notice of the applicant's claims is not a requirement in determining whether a dispute exists. ${ }^{171}$ However, by requiring the respondent to be aware its views were "positively opposed by the applicant", ${ }^{172}$ the Court is essentially requiring the respondent to have prior notice for a dispute to exist. ${ }^{173}$ This is because to satisfy the awareness requirement, the surest way would be for an applicant state to give prior notice of its legal claims to a respondent state before filing proceedings before the ICJ. ${ }^{174}$ The Court, unfortunately, gives no answer to this contradiction.

167 Federica I Paddeu "Multilateral Disputes in Bilateral Settings: International Practice Lags behind Theory" (2017) 76 CLJ 1 at 2.

168 Marshall Islands v United Kingdom, above n 1, at [10] per President Abraham.

169 Ranganathan, above n 105, at 89 .

170 Andrea Bianchi "Choice and (the Awareness of) its Consequences: The ICJ's 'Structural Bias' Strikes again in the Marshall Islands case" (2017) 111 AJIL 81 at 83.

171 Marshall Islands v United Kingdom, above n 1, at [38] and [45] per the majority.

172 At [41] per the majority.

173 Michael A Becker "The Dispute that Wasn't There: Judgments in the Nuclear Disarmament Cases at the International Court of Justice" (2017) 6 CILJ 4 at 10.

174 At 10; and Marshall Islands v United Kingdom, above n 1, at [31] per Judge Sebutinde (separate opinion). 
Furthermore, by requiring the respondent to be aware, the Court is shifting towards formalistic reasoning focusing on form and procedure. ${ }^{175}$ This is because, no matter the significance of the substance, the Court is able to dismiss a case on the narrow ground that a respondent was unaware its views were opposed by the applicant. Judge Crawford states that this approach "effectively turns a non-formalistic requirement into a formalistic one through the use of the term awareness. ${ }^{176}$ Ultimately, this requirement fits uneasily with the objective approach the Court has emphasised in the past and with statements made by the Court indicating that prior notice is unnecessary. ${ }^{177}$

\section{The cases relied upon by the Court}

The Court does not give any detailed legal reasoning when introducing the awareness requirement. The majority mentions that awareness is reflected in two previous cases and appears to interpret these cases as introducing awareness as a hard requirement in determining the existence of a dispute. ${ }^{178}$ This section proposes that a reading of the judgments may suggest otherwise.

(a) Alleged Violations of Sovereign Rights and Maritime Spaces in the Caribbean Sea (Nicaragua v Colombia)

The Court's reliance on Alleged Violations for its awareness requirement is troubling because at the time of the Marshall Islands' oral hearings, the judgment of that case had not been delivered. ${ }^{179}$ Therefore, the Marshall Islands (ironically) was not aware that there was an awareness requirement. The Court also did not appear to mention this new requirement during the proceedings.

In that case, the issue was whether a dispute existed between Nicaragua and Colombia. Nicaragua initiated proceedings relating to alleged violations by Colombia of Nicaragua's "sovereign rights and maritime zones". ${ }^{180}$ Nicaragua alleged that Colombia refused to comply with a 2012 ICJ decision declaring that certain maritime zones belonged to Nicaragua by continuing to assert its sovereignty. ${ }^{181}$ There were public statements to this effect made by high ranking Nicaraguan officials. ${ }^{182}$

175 Paddeu, above n 167, at 2; and Loris Marotti "Establishing the Existence of a Dispute Before the International Court of Justice: Glimpses of flexibility within formalism?" (2017) 45 QIL 77 at 88.

176 Marshall Islands v United Kingdom, above n 1, at [5] per Judge Crawford dissenting.

177 Bianchi, above n 170, at 83 .

178 Marshall Islands v United Kingdom, above n 1, at [41] per the majority.

179 Vincent-Joël Proulx "The Marshall Islands Judgments and Multilateral Disputes at the World Court: Wither Access to International Justice?" (2017) 111 AJIL 96 at 98.

180 Alleged Violations, above n 147, at [67] per the majority.

181 At [62] and [64] per the majority.

182 At [69] per the majority. 
The Court in Alleged Violations found that the public statements made by Nicaraguan officials indicated that prior to the application being filed, Columbia was aware that actions taken by them relating to Nicaragua's maritime zones were positively opposed by Nicaragua. ${ }^{183}$ However, the Court in Marshall Islands $v$ United Kingdom appears to have misinterpreted this as authority for the awareness requirement. ${ }^{184}$ In a statement made prior to this finding, the Court in Alleged Violations observed that a formal diplomatic protest brought to the attention of the other party is not a necessary condition and that determining the existence of a dispute is a matter of substance based on the examination of the facts. ${ }^{185}$ The Court also indicated that it was "apparent from these statements that the Parties held opposing views". ${ }^{186}$ Therefore, the finding that Columbia was aware was solely a description of a factual finding to further confirm that the applicant's claims were positively opposed and was not, as emphasised by Judges Sebutinde and Crawford, intended to be turned into a "formalistic legal requirement" of awareness. ${ }^{187}$ Furthermore, if it was the intention of the Court to deviate from past practice and make this an additional hard requirement in determining the existence of a dispute, then it would be reasonable to expect they would expressly mention this. ${ }^{188}$

(b) Application of the International Convention on the Elimination of All Forms of Racial Discrimination (Georgia v Russian Federation)

The case of Georgia v Russia involved the interpretation and application of the International Convention on the Elimination of Racial Discrimination (CERD) ${ }^{189}$ Georgia invoked art 22, alleging that Russia violated CERD. ${ }^{190}$ Article 22 was a compromissory clause which required states to first attempt a negotiated settlement before proceeding to the ICJ. ${ }^{191}$ The Court held that there was a

183 At [73] per the majority.

184 Maitê de Souza Schmitz "Decision of the International Court of Justice in the Nuclear Arms Race Case" (21 November 2016) Harvard International Law Journal <www.harvardilj.org>.

185 Alleged Violations, above n 147, at [72] per the majority.

186 At [69] per the majority.

187 Marshall Islands $v$ United Kingdom, above n 1, at [32] per Judge Sebutinde (separate opinion) and [6] per Judge Crawford dissenting.

188 At [33] per Judge Robinson dissenting.

189 International Convention on the Elimination of All Forms of Racial Discrimination 660 UNTS 195 (opened for signature 21 December 1965, entered into force 4 January 1969) [CERD].

190 Georgia v Russia, above n 147, at [1].

191 CERD, above n 189, art 22. 
dispute. ${ }^{192}$ However, it did not proceed to determine the merits of the case because the states did not comply with art 22 of CERD by attempting to negotiate a settlement before proceeding to the ICJ. ${ }^{193}$

The Court in Marshall Islands v United Kingdom relied on certain passages from the Georgia v Russia judgment when introducing the awareness requirement. Those passages referred to Russia's awareness of parliamentary statements made by the Georgian Parliament, ${ }^{194}$ and a press release made by Georgia's Foreign Ministry. ${ }^{195}$ Judge Robinson disagreed with the Court's use of those passages for introducing the awareness requirement. He stressed that those passages were emphasising whether the parliamentary statements and press release revealed a dispute and that the references to Russia's awareness were just findings of fact because it did not seem likely that the Court would introduce a hard requirement of awareness in such an "indirect and non-transparent manner". ${ }^{196}$ It also appears to be misleading that Georgia v Russian Federation stands for a formal requirement of awareness because the proceedings in that case followed an armed conflict between the two states and involved a compromissory clause requiring the parties to attempt a negotiated settlement before bringing the case to the ICJ. Therefore, it would appear logical that Russia would be aware that its views were opposed by Georgia because of their history of conflict and before a negotiated settlement would take place. ${ }^{197}$

\section{Impact of awareness on future cases}

The introduction of an awareness requirement appears to raise the threshold for a dispute to exist. ${ }^{198}$ It also places a higher burden on the applicant state to show that a dispute exists. ${ }^{199}$ This is not necessarily a negative implication. A higher threshold may influence some states to accept the jurisdiction of the Court as there will be greater scrutiny before a legal dispute is established and a claim proceeds on its merits. It would also promote certainty in international relations because by proving awareness, it gives the respondent state an opportunity to act in a specific way. This enables the Court to better determine whether the views of the parties are positively opposed.

192 Georgia v Russia, above n 147, at [113].

193 At [182].

194 Georgia v Russia, above n 147, at [62]-[89].

195 At [104].

196 Marshall Islands v United Kingdom, above n 1, at [28] and [34] per Judge Robinson dissenting.

197 Marshall Islands v United Kingdom, above n 1, at [33] per Judge Sebutinde (separate opinion); and Béatrice I Bonafé "Establishing the existence of a dispute before the International Court of Justice: Drawbacks and implications" (2017) 45 QIL 3 at 11.

198 Bonafé, above n 197, at 23.

199 Marshall Islands v United Kingdom, above n 1, at [1] per Judge Crawford dissenting. 
However, a higher threshold may work to limit access to the ICJ and may impact the ICJ's credibility as an effective avenue for dispute resolution between states. ${ }^{200}$ It could cause a case worthy of proceeding on its merits, based on its substance, to be dismissed because an applicant is unable to get over the "new hurdle" 201 of showing awareness on the part of the respondent. ${ }^{202}$ This runs counter to the Court's statements in previous cases where they have said they will always try where possible to entertain a case if it has a legal dimension. ${ }^{203}$

\section{Sound administration of justice and judicial economy}

A strong criticism amongst the dissenting judges is that the awareness requirement will impact the sound administration of justice and judicial economy in the ICJ. ${ }^{204}$ Vice-President Yusuf states that if the Court finds that the respondent was not aware that its views were positively opposed, then an applicant would be able to get around the awareness requirement by submitting a new application before the Court against the respondent. ${ }^{205}$ In these new proceedings, the previously unmet condition of awareness would be satisfied because the respondent would be aware its view were opposed from the previous proceedings. ${ }^{206}$ The consequences of this would create inefficiencies and may run the risk of the Court wasting its time hearing an identical case which could have been addressed much earlier. The Court has also stated in its jurisprudence that it should not penalise an applicant for a defect in procedure which can easily be remedied "by the date when the Court decides on the jurisdiction". ${ }^{207}$ The respondent's awareness that its views were opposed is something which the applicant may have been able to easily remedy. Therefore, it would not be in the sound administration of justice for an applicant to have to submit new proceedings in order to satisfy this requirement. ${ }^{208}$

200 Ingo Venzke "Public Interests in the International Court of Justice - A Comparison between Nuclear Arms Race (2016) and South West Africa (1966)" (2017) 111 AJIL 68 at 70.

201 At 70 .

202 Marshall Islands v United Kingdom, above n 1, at [5] per Judge Robinson dissenting.

203 Nicaragua $v$ United States, above n 101, at 27.

204 Marshall Islands $v$ United Kingdom, above n 1, at [24] per Vice-President Yusuf dissenting, [52] per Judge Robinson dissenting and 1038 per Judge Gaja.

205 At [24] per Vice-President Yusuf dissenting.

206 Vincent-Joël Proulx "The World Court's Jurisdictional Formalism and its Lost Market Share: The Marshall Islands Decisions and the Quest for a Suitable Dispute Settlement Forum for Multilateral Disputes" (2017) 30 LJIL at 934

207 Application of the Convention for the prevention and punishment of the crime of genocide (Croatia v Serbia) (Preliminary Objections) [2008] ICJ Rep 412 at [85].

208 Edoardo Stoppioni "The ICJ decision in the Marshall Islands cases or the unintended consequences of 'awareness'" (2016) 3 Quaderni SIDIBlog 339 at 341. 
It is important to note that this argument has no practical effect on the future of the alleged dispute between the Marshall Islands and the United Kingdom. In December 2014, the United Kingdom amended its declaration of acceptance of the Court's compulsory jurisdiction. It was amended to exclude "any dispute [that] is substantially the same as a dispute previously submitted by the same or another Party". ${ }^{209}$ In February 2017, it was further amended to exclude any claim regarding nuclear weapons: $:^{210}$

... unless all of the other nuclear-weapon States Party to the Treaty on the Non-Proliferation of Nuclear

Weapons have also consented to the jurisdiction of the Court and are party to the proceedings in question.

It is unlikely these conditions will be ever met. ${ }^{211}$ As such, due to the Court's formalistic and unprecedented requirement of awareness, the Court has again missed "a golden opportunity to advance the development of international law" regarding nuclear weapons. ${ }^{212}$

\section{B Monetary Gold Principle}

The judgment on the preliminary objections is unsatisfactory. The Court only determined that the case could not proceed because of an absence of a dispute and did not go on to consider the United Kingdom's other preliminary objections. ${ }^{213}$ However, it was acknowledged by Judges Tomka, Xue, Bhandari and Crawford that this was unsatisfactory and that the case could have been better decided based on the Monetary Gold principle. ${ }^{214}$

\section{What is the Monetary Gold principle?}

The principle in the Monetary Gold case applies where a third state, whose position would be affected by the decision, is not before the ICJ. ${ }^{215}$ In such a case, the Court cannot proceed to determine the merits of the case unless the third state also consents to come before the ICJ. ${ }^{216}$ However, for the

209 United Kingdom of Great Britain and Northern Ireland: Declaration Under Article 36(2) of the Statute United Nations C.N.828.2014.TREATIES-I.4 (Depository Notification) (2014).

210 "Declarations recognizing the jurisdiction of the Court as compulsory: United Kingdom of Great Britain and Northern Ireland", above n 92.

211 Becker, above n 173, at 20.

212 Tokarz, above n 116, at 756 .

213 Marshall Islands v United Kingdom, above n 1, at [58] per the majority.

214 At [39] per Judge Tomka (separate opinion), [11] per Judge Xue, [18]-[19] per Judge Bhandari and [32]-[33] per Judge Crawford dissenting.

215 Monetary Gold, above n 7, at 33.

216 At 33 
Court to refuse to exercise its jurisdiction, it must be shown that the legal interests of the absent state "would form the very subject matter of the decision".217

The Monetary Gold case illustrates how the principle applies. That case concerned a quantity of monetary gold that was removed from Rome in 1943 by the Germans. ${ }^{218}$ The gold was found by an independent arbitrator to belong to Albania. ${ }^{219}$ Italy claimed that it was entitled to the gold and subsequently brought proceedings to the ICJ against the Tripartite Commission for the Restitution of Monetary Gold which consisted of the United Kingdom, the United States and France. Italy requested the ICJ to determine how much of the gold it had claim to. ${ }^{220}$ However, the Court refused to exercise its jurisdiction. This was because Albania was absent from the proceedings and its legal interests in the gold formed the subject matter of the decision. ${ }^{221}$

\section{Application of the Monetary Gold principle in Marshall Islands v United Kingdom}

The NPT is a multilateral treaty requiring the cooperation of all states party to it to negotiate in good faith the cessation of nuclear weapons leading to disarmament. ${ }^{222}$ The Court would not be able to rule on the conduct of the United Kingdom without also needing to evaluate the conduct and lawfulness of other states who are party to the NPT. This is because the conduct of other states who are party to the NPT would also be at issue since the United Kingdom is required to negotiate with these other states to achieve the goals set out by the NPT. ${ }^{223}$ Therefore, the legal interests of other NWS, absent in these proceedings, would form the subject matter of the decision. ${ }^{224}$

\section{THE FUTURE OF NUCLEAR WEAPONS}

Nuclear weapons have evolved into an issue that affects the entire globe. ${ }^{225}$ This Part will address how issues of nuclear weapons may be approached in the future. First, it will examine whether the threshold for the ICJ to hear nuclear weapon cases should be relaxed and whether a people-centred approach to the issue should be taken. Secondly, it will examine whether the ICJ is capable of dealing

217 At 32 .

218 Monetary Gold, above n 7, at 21.

219 At 21 .

220 At 26.

221 At 32 .

222 NPT, above n 2, art VI.

223 Marshall Islands $v$ United Kingdom, above n 1, at [38] per Judge Tomka (separate opinion).

224 At [33] per Judge Crawford dissenting.

225 George RB Galindo "On Form, Substance, and Equality Between States" (2017) 111 AJIL 75 at 77. 
with issues regarding nuclear weapons. Finally, the reality of achieving nuclear disarmament will be addressed.

\section{A A Relaxed Threshold with a People-Centred Approach}

Judge Cançado Trindade emphasises that the ICJ should have shown sensitivity on this issue and "should have given its contribution to a matter which is a major concern of the vulnerable international community, and indeed of humankind as a whole". 226 This suggests that a lower threshold should be adopted by the Court in determining whether a case of global importance should proceed to the merits. ${ }^{227}$ It also suggests the focus should be centred around how the issue impacts the people of the world as opposed to the states subject to the proceedings. ${ }^{228}$ The case brought by the Marshall Islands was a case that reflected the concerns of the global community and which suggested the need for the Court to be more responsive to the questions raised. ${ }^{229}$ By taking such an approach, the ICJ "could have asserted itself and demonstrated the importance of the law in resolving crucial global issues". ${ }^{230}$

However, such an approach may present more difficulties than solutions. If the Court were to lower its threshold, then it is likely many NWS would decline to come before the ICJ due to the increased number of claims brought against them regarding their obligations under nuclear weapon treaties and customary international law. The difficulties of a lower threshold may also extend to the Court's ability to determine other issues of global importance, such as climate change. This is because many states, who are known to contribute high levels of greenhouse gases, would also decline to come before the ICJ. ${ }^{231}$ The Court may also run the risk of receiving an avalanche of cases and turning into a political forum because the focus may shift from deciding legal disputes between states to determining the impacts of and solutions to global issues.

\section{B The ICJ's Capability of Dealing with Nuclear Weapon Issues}

The issue of nuclear weapons is inherently political. ${ }^{232}$ This appears to be reflected in this case where all eight of the judges who found that a dispute did not exist were from NWS or from states

226 Marshall Islands v United Kingdom, above n 1, at [327] per Judge Cançado Trindade dissenting.

227 At [321] per Judge Cançado Trindade dissenting.

228 Galindo, above n 225, at 77.

229 Antony T Anghie "Politic, Cautious, and Meticulous: An Introduction to the Symposium on the Marshall Islands Case" (2017) 111 AJIL 62 at 64.

230 Bianchi, above n 170 , at 82 .

231 Anghie, above n 229, at 63.

232 Alberto Alvarez-Jimenez "The International Law Gaze: Marshall Island v United Kingdom" [2017] NZLJ 222 at 224. 
which benefit from nuclear deterrence offered by their allies. ${ }^{233}$ Interpreting this voting pattern, it appears likely that judges vote in favour of the national interests of their home state, rather than what is in the best interests of the international community as a whole. ${ }^{234}$ This can impact the ICJ's reputation as it is crucial for judges to be impartial and unbiased. ${ }^{235}$ It also undermines the Court's ability to function as a true "world court" on issues where opinions differ greatly among states. ${ }^{236}$ Therefore, the issue of nuclear weapons is arguably best dealt with through negotiations between states and the implementation of treaties.

However, proceedings before the Court do not appear to have the effect of the ICJ trespassing on the political process. Usually, the Court would be asked to rule on the obligations contained in nuclear weapon treaties, which are legal instruments devised by the international community. It is within the function of the Court to uphold and interpret these treaties. By doing this, the ICJ can put pressure on states and make it clear what their obligations are with respect to nuclear weapons, thus supporting the political process. ${ }^{237}$

The issue of nuclear disarmament is also of a collective character because it requires the cooperation of all NWS. ${ }^{238}$ For the Court to deal with nuclear weapon issues adequately, it requires all NWS to be involved in the proceedings. This is unlikely to happen. ${ }^{239}$ Furthermore, the bilateral function of dealing with a dispute between two states would have no practical effect on any nuclear weapon related issues. This is because if the ICJ did proceed to the merits and make an order requiring the state to negotiate and fulfil the precise result of nuclear disarmament, it is unlikely that anything of substance would happen without the cooperation of all other NWS.

An example can be found in the Marshall Islands $v$ United Kingdom decision. The United Kingdom possesses less than one per cent of the world's total nuclear arsenal. ${ }^{240}$ Therefore, the effect of any judgment would not lead to any progress of achieving nuclear disarmament when countries such as the United States and Russia, who possess over 90 per cent of the world's total nuclear arsenal,

233 Becker, above n 173, at 21.

234 Venzke, above n 200, at 72; and Bonafé, above n 197, at 19.

235 Statute of the International Court of Justice, art 20.

236 Bianchi, above n 170, at 87.

237 Anghie, above n 229, at 64; and Venzke, above n 200, at 71.

238 Marshall $v$ United Kingdom, above n 1, at [15] per the majority.

239 Becker, above n 173, at 20.

240 United Kingdom Ministry of Defence "UK nuclear deterrence: what you need to know" (24 March 2016) Gov UK <www.gov.uk>. 
do not consent to come before the Court in regard to nuclear weapon issues. ${ }^{241}$ It is also unrealistic to expect a state to unilaterally rid itself of nuclear weapons, particularly since one of the main justifications for possessing such weapons is deterrence against other NWS. ${ }^{242}$ As a result, it appears there is little the ICJ can do to address the issue.

\section{The Reality of Achieving Nuclear Disarmament}

There has been global momentum amongst states and citizens towards achieving nuclear disarmament since the Cold War. ${ }^{243}$ This momentum has been enhanced by a 2009 speech made by President Barack Obama (as he then was) where he discussed the necessity of realising a nuclear weapon free world. ${ }^{244}$ Momentum has also grown through the adoption of the Treaty on the Prohibition of Nuclear Weapons in 2017.

However, despite these efforts, the world is still a long way from achieving nuclear disarmament. NWS are not interested in signing a disarmament treaty, nor are they interested in participating in fora discussing the issue. ${ }^{245}$ This removes any legitimacy a disarmament treaty would have as legitimacy would be drawn from the NWS who become party to it and who ratify it. ${ }^{246}$

Moreover, as long as one NWS continues to possess nuclear weapons, other states will attempt to acquire them or continue to upgrade their existing arsenals. ${ }^{247}$ Consequently, the reality of ever achieving this objective is in doubt and it is unlikely we will ever escape this stalemate in our lifetime. Instead, we must accept that disarmament is a political game and unless the views of every state are in harmony, disarmament will never be achieved.

\section{CONCLUSION}

This article set out to evaluate the decision of the ICJ in Marshall Islands v United Kingdom. The Court did not proceed to the merits and dismissed the case because no dispute existed between the parties. Two arguments were advanced in criticising the reasoning in this case. First, the Court should

241 International Campaign to Abolish Nuclear Weapons "Nuclear Arsenals" <www.icanw.org>; and Arms Control Association "Nuclear Weapons: Who Has What at a Glance" (5 July 2017) <www.armscontrol.org>.

242 Thérèse Delpech Nuclear Deterrence in the 21st Century: Lessons from the Cold War for a New Era of Strategic Piracy (RAND, Santa Monica, 2012) at 13.

243 Hiroaki Nakanishi "Towards a Nuclear-Weapon Free World: How Can the World Resolve the Disharmony Between the UNSC and UNGA?" (2012) 43 VUWLR 617 at 618.

244 Barack Obama, President of the United States of America "Remarks of President Barack Obama" (speech to the people of Prague, Hradčany Square, Prague, 5 April 2009).

245 Ranganathan, above n 105, at 88. See also Venzke, above n 200, at 68.

246 M Patrick Cottrell The Evolution and Legitimacy of International Security Institutions (Cambridge University Press, New York, 2016) at 153.

247 At 172 . 
not have introduced a new requirement of awareness in determining the existence of a dispute because it appears to have deviated from the Court's past jurisprudence in treating the inquiry as an objective determination. Secondly, the Court should have addressed the other preliminary objections of the United Kingdom and dismissed the case on the grounds of the Monetary Gold principle because the interests of other NWS formed the subject matter of the decision.

The case also, again, illustrated the narrow reasoning adopted by the Court and its reluctance to deal with issues concerning nuclear weapons. It emphasised that the role of the Court on such issues of global significance is minimal and ought to be left to the political fora of the UN. It is only when all states come together in harmony will the world ever be free of such weapons capable of destroying us all. 